\title{
Іеор Смирнов,
}

доктор географрічних наук, профресор,

Київський національний університет

імені Тараса Шевченка,

Київ, Україна

Smirnov_IG@ukr.net

https://orcid.org/0000-0002-6395-7251

\section{КОМПЛЕКСНА ЛОГІСТИЧНА СТРАТЕГІЯ СТАЛОГО РОЗВИТКУ УРБОТУРИЗМУ: УКРАЇНСЬКИЙ ТА СВІТОВИЙ ДОСВІД}

Стаття присвячена обгрунтуванню комплексної логістичної стратегії розвитку урботуризму на основі досліджень українського та світового досвіду. Висновки. Визначено, що в комплексній структурі логістики туризму, логістиці рекреаційно-туристичних ресурсів належить важливе місце. Логістику ресурсної бази туризму можна розглядати на різних регіональних рівнях, починаючи від локального та закінчуючи найвищим - метарівнем. Отже, свою окрему ресурсну базу має кожен туристичний об'єкт, місто, туристична зона, область, регіон, країна, туристичний макрорегіон світу та світ загалом. Місткість ресурсної бази визначає місткість туристичного ринку певної території. Тобто поняття природноресурсного та рекреаційно-ресурсного потенціалів, місткість ландшафту та рекреаційних ресурсів взаємопов'язані та інтегруються в ширшу категорію логістичний потенціал рекреаційно-туристичних ресурсів (РТP) або ресурсної бази туризму (РБТ), який у системі логістики туризму певного регіону діє разом 3 логістичним потенціалом матеріально-технічної бази туризму та логістичним потенціалом вхідного туристопотоку в регіон.

Ключові слова: урботуризм, комплексна логістична стратегія, сталий туризм, український досвід.

Постановка проблеми. Розглядаючи можливості імплементації постулатів сталого розвитку урботуризму, як правило, говорять про параметри досягнення сталості, проте іноді простіше виокремити та визначити показники «несталості» ситуації. Якщо допустити, що процеси вважаються несталими, коли вони зменшують екологічні, соціальні та виробничі ресурси, від яких безпосередньо залежать процеси на обраному рівні, то це буде первинна несталість; якщо від них залежать процеси на інших рівнях - вторинна несталість.

Аналіз останніх досліджень. Питання сталого розвитку туризму та урботуризму та його перспектив досліджувало багато вітчизняних та закордонних вчених. Особлива увага дослідниками приділалась сталому розвитку туризму урботуризму, перспективній гілці туризму.Думку про стрімкий розвиток урботуризму розділяють багато інших вчених та дослідників цього напрямку туризму. Серед них О. Любіцева, С. Романчук, С. Дутчак, М. Дутчак, А. Ковальчук, М. Біржаков, А. Jackowski та ін. Кожен 
із них дає своє пояснення терміну «сталого розвитку» і наводить його відмінності від терміну «розвитку сталого туризму».

Виклад основного матеріалу. Поняття «сталий розвиток туризму» та його основні принципи визначила Світова туристична організація наприкінці 1980-х років.

Незважаючи на досить тривалий час розвитку цієї концепції, дослідники не дійшли спільної думки щодо дефініції сталого туризму. На сьогодні найпоширенішими з них є такі:

1) сталий розвиток туризму - це всі форми розвитку й управління туризмом, які не суперечать природній, соціальній, економічній єдності й добробуту сорормованих суспільств у безстроковому періоді (Світова федерація природних та національних парків, 1992);

2) сталий розвиток туризму забезпечується в межах екологічної стійкості, дає змогу ефективно відновлювати продуктивність природних ресурсів; враховує внесок місцевих громад у відпочинок туристів; передбачає рівність прав місцевого населення на економічні користі від туризму; ставить на перше місце побажання та потреби рецептивної сторони (Tourist Concern \& Wild World Fund, 1992);

3) сталий розвиток туризму дає змогу сучасним мешканцям планети задовольнити власні потреби у відпочинку та рекреації без загрози втрати цієї можливості майбутніми поколіннями (UNDP, Production and consumption branch, 1998).

Згідно 3 «Порядком денним на XXI століття» принципи сталого розвитку туризму такі:

1) сприяння утвердженню повноцінного та здорового життя людини в гармонії з природою;

2) внесок у збереження, захист і відновлення екосистем Землі;

3) розроблення і застосування сталих моделей виробництва та споживання як основа для подорожей і туризму;

4) співпраця народів у сфері відкритої економічної системи;

5) скасування тенденцій протекціонізму у сорері надання послуг туристичного характеру;

6) обов'язковий захист довкілля як невід'ємна складова процесу розвитку туризму, повага відповідних законів;

7) участь громадян країни у розв'язанні проблем, пов'язаних із розвитком туризму» в тому числі тих, що стосуються їх безпосередньо;

8) забезпечення локального характеру прийняття рішень щодо планування туристичної діяльності;

9) обмін досвідом та впровадження найефективніших технологій туризму;

10) урахування інтересів місцевого населення.

На сучасному етапі сутність сталого розвитку туризму розглядається як найважливіший фрактор сталого розвитку суспільства загалом. Це положення чітко зафіксовано в Глобальному етичному кодексі туризму, ухваленому СТО в 1999 р. У ньому проголошено зобов'язання всіх 
учасників туристичного процесу зберігати природне середовище з метою стійкого та збалансованого розвитку. Важливе місце належить ролі органів центральної, регіональної та місцевої влади, які мають підтримувати найбільш сприятливі для природного середовища форми туризму. 3 метою зміни негативного впливу великих туристичних потоків слід застосовувати заходи рівномірного розподілу туристів і відвідувачів, зменшуючи таким чином дію фрактора сезонності. Планування нових об'єктів туристичної інфрраструктури потрібно здійснювати з урахуванням особливостей місцевості, гарантувати збереження звичного способу життя населення. Сталий розвиток територій, залучених для туристичної діяльності, забезпечують шляхом створення об'єктів інфраструктури туризму, організації нових робочих місць, залучення до нової діяльності у сфері туристичного обслуговування місцевого населення. У результаті цього підвищується життєвий рівень мешканців периферійних регіонів, відбувається їх закріплення на історичній території проживання. Природоохоронний характер туризму натомість полягає в обов'язковості збереження біорізноманіття рекреаційних територій та центрів. Для цього використовують природоохоронні технології, практичні доробки, рекомендації фрундаментальних і прикладних наук. Важливе значення в охороні та відновленні рекреаційних територій мають також схеми фрінансування і кредитування природоохоронної діяльності в їх межах.

Значну роль у такому контексті відіграє фрормування екологічного світогляду як населення рекреаційних регіонів, так і туристів. Насамперед, усвідомити рекреаційну привабливість природного ландшафрту, його еколого-естетичну цінність, що може приносити економічну вигоду, а тому потребу охорони і дбайливого ставлення до рекреаційних ресурсів. Розуміння місцевим населення того, що хижацьке застосування ресурсів призведе до тієї обставини, що їх територія залишиться за межами сфери рекреаційного використання, може бути значним стимулом для дбайливого та раціонального користування ресурсами. Стосовно туристів, то їм теж варто зрозуміти необхідність приймати правила, які диктує природа, тобто дотримуватися ресурсних обмежень. Це означає забезпечення відповідногорівня інформованості про умови перебування. Від туристів потрібні: згода поступитися певною часткою свого комфорту; надання переваги продукції, виробленій в цьому регіоні; інтерес і повага до місцевих звичок, традицій та прийнятого способу життя; згода користуватися лише громадським транспортом; ентузіазм щодо активного захисту довкілля, мінімізація негативних наслідків від рекреаційної діяльності; збільшення часу перебування на відпочинку за рахунок зменшення частоти подорожей. Отже, за сталого розвитку туризму всі рекреаційні ресурси використовують та спрямовують таким чином, щоб задовольняти економічні, соціальні й естетичні потреби під час одночасного збереження культурної ідентичності, екологічної рівноваги, біологічного різноманіття та систем життєзабезпечення регіону відпочинку. 
Україна, хоча й ратифрікувала міжнародні документи з питань екологічної безпеки, однак не має значних досягнень у галузі практичного застосування принципів сталого розвитку. На нашу думку, насамперед, потрібно застосовувати такі заходи з активізації роботи в цьому напрямі:

1) затвердження на державному рівні положень сталого розвитку, зокрема щодо туризму;

2) співпраця та обмін досвідом із міжнародним співтовариством з питань теорії та практики сталого розвитку, адаптація їхніх методів та інструментів для України;

3) підвищення рівня екологічної свідомості населення, поширення інформації про якість навколишнього середовища та методи його охорони;

4) економічна та правова підтримка природоохоронної діяльності;

5) стимулювання природоохоронних ініціатив населення шляхом підтримки неурядових організацій.

Новизна ефрективність логістичного підходу до розв'язання проблем сталого розвитку туризму полягають в комплексному системному способі, за яким в єдину логістичну модель поєднуються туристичнорекреаційні ресурси регіону, матеріально-технічна база туризму (iї розглядають як сукупність засобів розміщення туристів, їх харчування, транспортування та програмного забезпечення) та вхідний туристопотік у регіон. Інтегруючим показником у логістичній моделі сталого розвитку туризму $є$ логістичний потенціал (або пропускна спроможність), який визначають окремо як у разі туристичних ресурсів (об'єктів), так і щодо матеріально-технічної бази, а також туристопотоку Логістичну модель сталого розвитку туризму розробив автор на підставі класичного логістичного методу «точно в термін» (Just In Time (JIT)) та відповідної логістичної системи «Pull» (у перекладі з англ. - «тягнуча»).

Головна проблема логістики туризму па рівні країни, регіону узгодження обсягів туристично-ресурсного потенціалу, туристичного господарства, туристичної інфраструктури (зокрема транспортної) та логістичних потоків. Особливість туризму як галузі ссрери послуг полягає в тому, що її основу становить туристично-рекреаційний потенціал. Україна має значний туристично-рекреаційний потенціал, який визначається: особливістю «ії географічного положення та рельєфу; сприятливим кліматом; багатством природних, історико-культурних і рекреаційних ресурсів. Водночас за рівнем розвитку туристичної галузі наша країна відстає від світових лідерів: якщо США отримують сукупний річний дохід від туризму в обсязі 100 млрд дол. США, Італія, Франція, Іспанія - 40-50 млрд, то Україна - лише 4 млрд дол. США (20-те місце серед країн світу). Якщо оцінити річний обсяг послуг, наданих суб'єктами туристичної діяльності України, то він дорівнює менше 1 \% ВВП держави (на рівні 500 млн дол. США), що в розрахунку на одного мешканця становить 10 дол. США (один із найнижчих показників у Європі). Туристичне господарство України охоплює 2,5 тис. ліцензованих 
туристичних підприємств; понад 1400 готелів, мотелів, турбаз, кемпінгів; 3 тис. санаторіїв. Незважаючи на це, в туристичний сезон постійно не вистачає місць для розміщення туристів в основних туристичних центрах і зонах України, зокрема в м. Києві, на Південному березі Криму, в Карпатах тощо, а в інших регіонах спостерігається недобір туристів за відносно розвиненої туристичної інфраструктури.

Вирішити таку проблему й забезпечити сталий розвиток туризму в Україні можна шляхом застосування логічного підходу «точно в термін» на мезо- та макрорівнях туристичного господарства, тобто в межах курортополісів, окремих туристичних центрів і зон, а також областей України і всієї держави. В логістиці цей підхід розглядають, як: 1) виробничу фрілософрію, спрямовану на безперервне вдосконалення і таку, що базується на послідовному усуненні всього зайвого, тобто того, що спричинює підвищення вартості продукції, не збільшуючи при цьому її споживчої цінності; 2) у вужчому розумінні поставка необхідних матеріалів у потрібне місце на певний час, що передбачає високий ступінь синхронізації виробничих операцій.

Підхід «точно в термін» характерний для так званої витягаючої технології в логістиці (або «Рull-системи»). Навідміну від штовхаючої системи («Рush»), яку вважають більш консервативною бюрократизованою, менш пов'язаною з ринком, «Рull-система» - сучасне логістичне втілення ідеї «гнучкого» виробництва, що динамічно змінюється згідно з особливостями ринкового попиту. Отже, в системах промислової та торговельної логістики початковою (програмувальною) ланкою є ринковий попит, відповідно до особливостей якого виробляють та реалізують товари.

У логістиці туризму простежується зворотна ситуація, оскільки початковою (i програмувальною) ланкою визначають туристичнорекреаційні ресурси, згідно з логістичним потенціалом (пропускною спроможністю або рекреаційною місткістю) яких мають формуватися потоки туристів, а їхні потреби разом з туристичними послугами у місці споживання (проживання, харчування, перевезення, програмноінформаційне об слуговування) варто забезпечувати шляхом розвитку відповідної туристичної інфрраструктури (господарства, матеріальної бази). Отже, логістика туризму, використовуючи підходи «Рull» i «точно в термін», пропонує принципову модель сталого розвитку туризму.

необхідною умовою сталого розвитку туризму в регіоні, країні $€$ менший обсяг логістичного потенціалу матеріально-технічної бази стосовно логістичного потенціалу туристичного ресурсу (об'єкта). У свою чергу, відповідність ЛП МТБ до логістичного потенціалу потоку туристів визначається чисельністю туристів, котрі прагнуть використати (спожити) туристичні ресурси регіону (місцевості) протягом року, сезону, місяця, доби. Ця кількість туристів може дорівнювати показнику логістичного потенціалу (пропускної спроможності або місткості туристичної території, місткості розміщення) матеріально-технічної бази або бути меншою, але 
в жодному разі не перевищувати його. У протилежному випадку з'являються «дикі» туристи, різко погіршується комфортність відпочинку, збільшується туристичне навантаження на рекреаційні ресурси й об'єкти місцевості, регіону, країни, що неодмінно зумовлює їх деградацію. Прикладом останнього підходу є Ближні печери Києво-Печерської лаври (iї занесено до списку об'єктів Всесвітньої спадщини ЮНЕСКО, що існує вже понад 1000 років, у них розміщені мощі більше ніж 120 християнських святих, серед яких Нестор Літописець, Ілля Муромець, цілитель Агапіт та ін.), які внаслідок щоденних, неконтрольованих, надмірних туристопотоків протягом багатьох років зазнали зміни мікроклімату (температура, вологість, вміст $\mathrm{CO}_{2}$ ), що, поряд 3 іншими чинниками, призвело до обвалу частини печер у 2005-2006 рр.

У цій моделі перше співвідношення $1 €$ запобіжником першого рівня щодо збереження туристичних ресурсів, а друге, крім того, що відіграє роль запобіжника другого рівня, забезпечує й бізнесову ефективність використання туристичних ресурсів регіону, країни. У такій моделі розрізняють інформаційні потоки двох видів: 1) інформація стосовно максимально можливого потоку туристів для певного ресурсу (об'єкта), надана державним органам управління (на нашу думку, її обов'язково слід указувати в рекреаційному паспорті ресурсу (об'єкта); 2) інформація, яку туроператори надають (вони звичайно володіють матеріальнотехнічною базою туризму в регіонах) фрірмам-турагенціям - скільки та які путівки пропонуються для продажу.

Узгоджувальним показником сталого, збалансованого розвитку туризму в регіоні, країні $€$ логістичний потенціал, який стосовно рекреаційно-туристичних ресурсів означає максимально можливу чисельність відвідувачів (туристів) за певний період часу (рік, сезон, місяць, день), що не зашкодить стану туристичного ресурсу (об'єкта), екологічному навколишньому середовищу, забезпечить необхідний рівень комфорту туристів, не порушить усталений спосіб та умови життя місцевого населення. Слід враховувати, що у разі перевищення логістичного потенціалу логістичних ресурсів виникають різноманітні ризики (від яких, до речі, на сьогодні в Україні ніхто не застрахований), серед яких основними вважають такі: екологічний (погіршення стану навколишнього природного середовища); деструктивний (руйнування туристичного ресурсу (об'єкта); медичний (погіршення самопочуття та здоров'я туристів); охоронний (загострення проблем їх безпеки) тощо. ЛП PTP регіону, країни рекомендують визначати з урахуванням їх поділу на природно-рекреаційні та культурно-історичні (кожен з них, у свою чергу, ще поділяється та має особливості обчислення логістичного потенціалу), а також слід мати на увазі, що логістичний потенціал рекреаційнотуристичних ресурсів регіону можна істотно збільшити за допомогою штучно створених туристичних об'єктів.

Як приклад до останньої тези розглянемо характеристику одного з двох найбільших у США та світі тематичних парків розваг «Діснейворлд»1. 
Це одна з найбільших туристичних атракцій штату Флорида (у перекладі «Світ Діснея») та Диснеївський туристичний центр № 2, оскільки № 1 розташований у Каліфорнії - «Діснейленд» («Земля Діснея1»). Його відкрив У. Дісней у 1955 р. у передмісті м. Анахайм, він мав площу 32 га. «Діснейворлд» створили в 1971 р. уже після смерті У. Діснея (1966), який першим у світовому туризмі розробив та втілив в життя концепцію тематичних парків як нових місць відпочинку. «Діснейворлд» розміщений недалеко від міст Орландо й Тампа, і до нього ведуть декілька шосе загальнодержавного та регіонального значень. Також сюди можна долетіти літаком, власне до міжнародного аеропорту Орландо, звідки «автобуси-човники» доставлять туристів до готелю «Дісней-Ворлд Резорт». Парк розваг має спеціальну угоду з авіакомпанією «Дельта Ейрлайнз», яка $є$ його офріційним повітряним перевізником та має свій офріс в одному з готелів. Щодо перевезення туристів назад до аеропорту Орландо, то «автобуси-човники» на шляху до нього зупиняються біля кожного готелю «Діснейворлду». Парк розваг займає величезну територію, яка поділяється на декілька частин: «Чарівне королівство», «Річкова країна», «Острів відкриттів», «Острів задоволення», «Затока тайфунів», «Ералцентр», а також кіностудія «Дісней - Метро Голдвін Мейєр». їх з'єднує мережа внутрішніх автодоріг Парку розваг, серед яких Ворд Драйв, Буена-Віста Драйв та ін. Кожна частина «Діснейворлду» має декілька готелів, які відповідають найрізноманітнішим уподобанням туристів. Наприклад, у «Чарівному королівстві» розташовані готелі: «Гранд-готель» на пляжі біля озера, «Готель у Полінезійському стилі», «Готель у сучасному стилі», «Готель у примітивному стилі Дикого Заходу», «Готель та табір у примітивному стилі». Біля готелю багато гольфових клубів, де можна замовити гольф-курс. Оплатити перебування в готелях «Діснейворлду» можна за допомогою кредитних карток Амерікен Експрес (офіційна картка Парку розваг), Мастер Кард, Віза, а також власними кредитними картками Діснея. До речі, в Діснейворлді використовують власні «гроші» - долари Діснея (на однодоларовій купюрі зображений Міккі Маус, на п'яти доларовій «адмірал» Гуфрі, на десятидоларовій - Мінні Маус). Цими грошима також користуються в мережі магазинів «Дісней сторз», що розміщені по всій країні. Обмінний курс долара Діснея до долара США становить 1:1. Долар Діснея - «конвертована валюта», отже, ії без проблем обмінюють на американські долари за зазначеним вище курсом. Якщо турист живе в готелях Діснейворлду та має готельну картку, він може безкоштовно та без обмежень: користуватися транспортною системою Парку розваг; відпочивати на всіх пляжах та інших рекреаційних зонах Парку, а також плавати у басейнах готелю; користуватися знижками в магазинах і ресторанах. «Діснейворлд» розрахований, насамперед, на дитячий та родинний туризм, тому найголовніші атракції та події тут пов'язані 3 улюбленими героям мульторільмів У, Діснея. Зокрема, це урочистий парад мультгероїв Діснея; можливість пообідати з Мікі Маусом або іншим 
персонажем та отримати його автографр; участь у балу, присвяченому ляльці Барбі (остання разом із Кеном - артисти вдягнуті у відповідне вбрання) тощо. Програми та ціни таких шоу відрізняються залежно від віку туристів: дорослі, молодь, діти до трьох років. Останніх на час імпрези можна залишити в спеціальних дитсадках, де за ними наглядатимуть та нададуть їм усі відповідні умови для розваг. Вартість обіду з одним із Маусів досить помірна: 12,95 дол. США для дорослого, 7,95 - для дітей. Можна купити «тур» на перебування протягом 5-7 днів на «Острові задоволення» або в «Чарівному королівстві», але після сьомої години вечора дітям та молоді до 18 років бути тут без батьків не дозволяють.

Окрім зустрічей з Маусами, у «Діснейворлді» пропонують безліч інших розваг, цікавих як для дітей, так і дорослих. Серед них: відвідання «Замку жахів» із фрільму «Сутінкова зона»; подорож у спеціальній капсулі «людським тілом», тобто моделлю збільшених у тисячі разів внутрішніх органів людини; участь у спектаклі «Красуня та чудовисько»; катання (спуск) у спеціальному човні через 20 водоспадів у «Вризових горах»; участь у Полінезійському та Тропічному ревю, а також у музичному видовищі з життя американських «піонерів»; похід у зоопарк (120 видів тварин, 250 видів рослин) тощо. Діснейворлд - це ще й «царство торгівлі». За побажанням покупців куплені товари безкоштовно доставляють до готелю або відсилають до міста проживання туриста за помірну плату. Особливо багато магазинів у «Чарівному королівстві» (понад 50) та «Ерсої,» (понад 70, причому в кожній крамниці представлено окрему країну з відповідними товарами). А в «Дісней - Метро Голдвін Мейер Студіо» $є$ спеціальний магазин, в якому можна придбати речі, що належали відомим кіноартистам США (Метро Голдвін Мейєр, одна 3 найбільших американських кінокомпаній), а також різноманітні сувеніри від Уолт Дісней Продакшн. «Діснейворлд» має навіть власний банк - Сонячний банк, в якому пропонують повний перелік банківських послуг, включаючи обмін іноземної валюти. Його відділи та банкомата розміщені в усіх готелях Парку розваг. $€$ прокатна служба, де можна взяти камеру, авторемонтні та автопрокатні центри, причому «Діснейворлд» має свою автопрокатну фрірму. Тут розташована навіть церква, де відбуваються католицькі та протестантські служби. Екскурсійне бюро Парку розваг пропонує чотиригодинні екскурсії, а також УІР-тури. Парк розваг має власний канал «Дісней Ченнел», а також інші канали (майже 70) у кабельній мережі, що обслуговує всі готелі «Діснейворлду». Пропонують також спеціальне обладнання та послуги для туристів з особливими потребами (інвалідів). Загальна кількість відвідувачів досягає декілька десятків тисяч на день та декілька мільйонів за рік (2005 р. - 13 млн). За зразком «Діснейленду» та «Діснейворлду» подібні парки розваг створені в Європі та Азії, наприклад, «Євро Діснейленд» у Парижі, «Токіо Діснейленд» в Японії, «Європа-парк» в Німеччині, «Ліннамякі» у Фінляндії, «Леголенд» у Данії та ін.

Із принципової логістичної моделі сталого розвитку туризму зрозуміло, що її головна складова - потік туристів, які прибувають у місця 
розташування туристичних ресурсів. Ці потоки дуже різноманітні за складом туристів, їх потребами, маршрутами (дестинаціями), фінансовими можливостями тощо, але в місці споживання туристичної послуги (на туристичному об'єкті) потоки туристів можна визначити за допомогою таких уніфікованих показників, як: 1) потужність туристопотоку (число туристів на певний часу); 2) інтенсивність туристопотоку (кількість туристів за певний період часу); 3) щільність туристопотоку (густота туристів на км2 рекреаційної площі на певний час); 4) ритмічність туристопотоку (його надходження через певні відрізки часу).

Визначаючи логістичний потенціал вхідного потоку туристів у регіон, країну, слід також розрізняти такі його різновиди, як проектний, прогнозний і фактичний. Проектний потік туристів - це максимально можлива (допустима) його величина, на нашу думку встановлена за логістичний потенціалом туристичного ресурсу (його слід вказувати в рекреаційному паспорті ресурсного об'єкта). Прогнозний потік туристів виявляється на підставі маркетингових досліджень на черговий рік (а також сезон, місяць, день). Зрозуміло, що він не має перевищувати відповідний проектний потік. Фактичний може відрізнятися від прогнозного, як правило, убік зменшення внаслідок різних форсмажорних обставин (наприклад, у зв'язку з так званим карикатурним скандалом 10 тис. данців відмовилися від уже запланованих і оплачених турів у Єгипет у лютому 2006 р.).

Розрахунки логістичного потенціалу матеріально-технічної бази туризму здійснимо на прикладі готельних послуг. Показник місткості готельних послуг регіону (міста) визначається загальною сумою інвентарних готельних місць у всіх готелях (Г):

Місткість готельного ринку поділяється на дві частини - заповнену і незаповнену. Перша (+Мгр) вираховується за сумою зайнятих ліжкомісць (3) у всіх готелях, що утворюють місткість ринку цих послуг:

Незаповнену частину ринку готельних послуг (-Мгр) обчислюють сумою незайнятих ліжкомісць в кожному готелі (//), що утворюють єдиний ринковий простір:

Властивість ринку готельних послуг мати позитивний або негативний попит дає змогу застосовувати індекс попиту (7п), який визначається відношенням заповненої частини (позитивного попиту) та позаповненої частини (негативного попиту) до загальної місткості ринку готельних послуг регіону:

Показник, що перевищує більшу частину ринку готельних послуг у позитивному або негативному попиті, визначатиме становище ринку готельних послуг у регіоні. Подібним чином слід оцінити інші можливості розміщення туристів у регіоні - в санаторіях, пансіонатах, будинках і базах відпочинку, кемпінгах, турбазах, оздоровчих таборах тощо. Це стосується також культурно-пізнавальних та спортивних закладів (будинків культури, музеїв, театрів, басейнів, стадіонів, гральних майданчиків тощо). 
Джерелами організованих туристичних потоків, що прибувають у регіон, країну з метою «споживання» рекреаційно-туристичних ресурсів, $€$ туристичні фірми (переважно турагенції). Саме вони відіграють важливу роль логістичного «перетворювача» туристичних потоків: зі стохастичних, нестабільних, нерівномірних, некерованих, безперервних потоків клієнтів (що пояснюється характером попиту на турпослуги) турфірми формують туристичні групи (організовують дискретні, детерміновані, ритмічні та регулярні потоки туристів), які направляють в обрані споживачами місця відпочинку (або місця споживання туристичної послуги).3 погляду логістики туризму та вимоги сталого розвитку галузі завдання турфірми полягає в такій координації дій з туроператорами, щоб забезпечити оптимальні обсяги туристопотоків у місцях виробництва і споживання туристичних послуг з метою виконання умови, втіленої у принциповій моделі сталого розвитку туризму. При цьому в діяльності турфірм може спостерігатися «Push» та «Pull»-підходи. Перший виявляється, коли на певний туристичний ресурс (об'єкт) фрірми «виштовхують» потоки туристів, чисельність яких збільшується, унаслідок чого виникають різноманітні проблеми та ризики, пов'язані з туристичним перевантаженням, що може призвести в результаті до руйнування та зникнення туристичного ресурсу (його деградації). Сутність другого, «Рull-підходу», полягає в тому, що обсяг туристичного потоку в певний туристичний регіон (місце) має регулюватися та визначатися логістичним потенціалом ресурсної бази туризму, тобто не перевищувати максимально допустимої величини, за якої з'являються різні проблеми та ризики, що зменшують якість відпочинку та ефективність туризму. Саме «Рull-підхід» $є$ основою розгорнутої моделі сталого розвитку туризму в регіоні, країні. Отже, рекреаційно-туристичні ресурси регіону визначають його комплексний логістичний потенціал із туризму, до складу якого входять: 1) логістичний потенціал (рекреаційна місткість) кожного виду туристичних ресурсів та об'єктів; 2) логістичний потенціал матеріально-технічної бази туроператора (туроператорів), що передбачає також встановлення обсягів виробництва супутніх послуг і туристичних товарів у регіоні (перший потенціал має бути більший за другий); 3) логістичний потенціал (відповідних параметрів) вхідних туристопотоків, які в сукупності ніколи не повинні перевищувати ЛП МТБ туризму у регіоні, що досягається шляхом регулювання кількості путівок, наданих туроператорами для реалізації турагенціям, що розміщені в регіонах попиту натуристичні послуги. Реалізація «Рull-підходу» в розвитку туризму в регіоні неможлива без державної підтримки, оскільки не здатні окремі турфірми, навіть великі, формувати та модернізувати матеріально-технічну базу туризму в регіоні (особливо новостворюваної). Але розвиваючи туристичну індустрію в регіоні, варто застосовувати логістичні принципи, зокрема «Рull-підхід» та концепцію «точно в термін».

Це означає, що створюючи або розширюючи туристичні зони (центри), представники державних структур мають попередньо визначити 
логістичний потенціал їх ресурсної бази, тобто розрахувати максимально можливу кількість туристів (безпечний показник туристичного навантаження на певну ресурсну базу). Відповідно потрібно, щоб державні органи контролювали будівництво об'єктів МТБ туризму в цих зонах (центрах) з тією метою, аби ЛП МТБ не перевищував логістичного потенціалу ресурсної бази туризму (ЛП РБТ). Таким чином і туристичний потік перебуватиме в безпечних межах. Особливо актуальним зазначений підхід $€$ в екологічно чутливих регіонах. Наприклад, у Росії гірськолижний курорт «Красная Поляна» біля Сочі має максимальні можливості ресурсної бази щодо прийому туристів (тобто ії логістичний потенціал) - 29 тис. осіб, а об'єктів матеріально-технічної бази туризму вже побудовано з розрахунку на 36 тис. туристів. Тому спорудження нових готелів та інших об'єктів МТБ нині тут заборонено, оскільки подальше збільшення ЛП МТБ та відповідного потоку туристів може призвести, за висновками фахівців, до танення гірських снігів. Подібна проблема вже в найближчі роки може постати в карпатському гірському курорті Славське, який витримує максимальний туристопотік взимку 14 тис.осіб. На думку мера Славського М. Кінаша таке незабаром станеться, і тоді почнуться проблеми1. У Криму представники влади переконані, що слід обмежити потік туристів до реліктових хвойних лісів на Південному березі, адже це спричинює лісові пожежі (наприклад, події літа 2007 р.).

Отже, для державних органів можна запропонувати алгоритм логістичного оцінювання (аудиту) рівня сталості туристичної індустрії в регіоні та трьох відмінних стратегій - у разі моделі розвитку туризму, моделі розвитку МТБ або кризової моделі. Основою алгоритму здійснення логістичного аудиту е складання логістичної моделі сталого розвитку туризму в регіоні. Для цього попередньо потрібно здійснити логістичне оцінювання природно-рекреаційних та історико-культурних ресурсів і визначити ЛП РБТ, ЛП МТБ та логістичний потенціал вхідного туристопотоку в регіон (ЛП ТП). Застосувавши принципову логістичну модель сталого розвитку туризму, отримаємо три логістичні моделі стану туризму в регіоні: модель розвитку туризму, модель розвитку МТБ і кризову модель. Модель розвитку туризму відповідає ситуації ЛП РБТ, ЛП МТБ, ЛП ТП, за якої можливості ресурсної бази туризму щодо прийому туристів значно перевищують потужності матеріально-технічної бази туризму та відповідний туристопотік (ЛП МТБ і ЛПТП у більшості випадків $€$ близькими величинами). За цієї моделі рекомендують застосовувати стратегію (заходи) розвитку туризму в регіоні шляхом розбудови МТБ та маркетингово-рекламної діяльності з залучення нових туристів. Натомість протилежна кризова модель виникає, коли ЛП РБТ й ЛП МТБ, ЛП ТП, тобто можливості ресурсної бази Туризму стосовно прийому туристів зменшуються унаслідок надмірного туристопотоку, який стимулюється збільшеними потужностями матеріально-технічної бази. За кризової моделі потрібно вживати заходи щодо обмеження розвитку 
туризму в регіоні шляхом стримування будівництва нових об'єктів МТБ і зменшення вхідного потоку туристів. До важливих складових такої моделі також належать еколого-просвітницькі заходи, пов'язані зі збереженням та підновленням ресурсної бази туризму в регіоні, та постійний контроль (моніторинг) її стану. Останній компонент не зайвий i в моделі розвитку туризму, і в моделі розвитку МТБ (про неї йтиметься далі), в яких теж обов'язково варто здійснювати ці заходи з метою збереження та підтримування сталого розвитку туризму в регіоні на перспективу. Третя модель - модель розвитку матеріально-технічної бази туризму в регіоні нині спостерігається в багатьох регіонах України, багатих на рекреаційні ресурси та в яких $є$ фактичний (або можливий за невеликих маркетингових зусиль) потужний туристопотік. При цьому відстає розвиток МТБ туризму як за ії величиною (потужністю), так і за якістю (відповідністю до міжнародних та європейських стандартів). Таку ситуацію відображає рівняння ЛП РБТ > ЛП МТБ « ЛП ТП. Стратегія (заходи), що рекомендується за цією моделлю, передбачає термінове розширення МТБ туризму в регіоні, що може принести значний соціально-економічний ефеект та бізнесові прибутки за невеликих витрат.

Зазначені вище теоретичні положення щодо застосування логістичного підходу й аудиту до сталого розвитку туризму в регіоні, країні розглядають на прикладі України. Зокрема, це м. Бердичів Житомирської області, в якому розміщена така значна кількість цінних та цікавих туристичних об'єктів, що в літературі це місто називають «коштовним діамантом європейської цивілізації, архітектурним пам'ятником, де поєдналися українська, польська, єврейська, французька, італійська культури». Серед найвидатніших туристичних об'єктів Бердичева - монастир Босих Кармелітів (XVI-XVII ст.), костел Св. Варвари (1826), прилегла до них стара частина міста, в архітектурі якої поєднуються такі стилі, як бароко, класицизм та еклектика. 3 цим містом пов'язані імена славетних французьких (О.де Бальзак), англійських (Дж. Конрад), польських (Ю. Словацький, Ю. Крашевський, С. Сєраковський, М. Грабовський, М. Чайковський, Т. Бобровський), єврейських (Шолом-Алейхем, М. Мойхе-Сфорім) письменників і поетів. Тут розташовані історичні пам'ятки промислової (пивоварний завод) та торговельно-банківської архітектури. 3 Бердичева починаються цікаві радіальні тури до Житомира, Новоград-Волинського (батьківщина Лесі Українки), сіл Верхівня (палац Б. Ганської, дружини О. де Бальзака), Романівна (пов'язаного 3 М. Рильським), Терехове (народився Дж. Конрад). Звідси подорожують до Києва, Львова, Вінниці, Умані, Кам'янця-Подільського, Чернівців. Ллє з іншого боку, як зазначено в науковій літературі, розвитку туризму на Бердичівщині перешкоджає брак достатньої матеріально-технічної бази для приймання та обслуговування туристів (зокрема, готельно-ресторанного господарства); недостатній благоустрій транспортних комунікацій (як у власне туристичних районах, так і на під'їзних шляхах до них); занедбаний стан 
багатьох історичних пам'яток та архітектурних об'єктів (наприклад, у маєтку Ганських у с. Верхівня (початок XIX ст.) донині «квартирує» сільськогосподарський технікум, що перешкоджає створенню повноцінного меморіального музею О. де Бальзака). Отже, туристично-ресурсний потенціал Бердичівщини $€$ цілком достатнім, щоб привернути значні потоки іноземних туристів з Польщі, Ізраїлю, Франції, Великої Британії, Білорусії, Росії та інших країн, а також українських рекреантів та екскурсантів. Водночас розвиток матеріально-технічної бази туризму й туристичної інфрраструктури в м. Бердичеві та районі ще не відповідає його могутнім туристично-рекреаційним прихованим можливостям, що перешкоджає ефективному розвитку туристичної галузі в регіоні, отже, гальмує комплексний соціально-економічний розвиток регіону.

Особливість туристичної галузі, на відміну від інших галузей сфери послуг, полягає в ії безпосередньому поєднанні з ресурсною базою, тобто рекреаційно-туристичними ресурсами. На це неодноразово звертають увагу в словнику-довіднику «Туризм, гостинність, сервіс». Так, при визначенні сутності поняття «місткість туристичного ринку» зазначають, що вона, насамперед, зумовлюється пропускною спроможністю туристичного об'єкта (ресурсу) та ступенем розвитку відповідної інфрраструктури. Під час розгляду поняття «туристичне споживання» особливу увагу звертають на його специфріку, яка полягає в тому, що не товар доставляють споживачу, а, навпаки, споживач (турист) прибуває до місця виробництва турпродукту, аби його спожити (тобто до туристичного ресурсу (об'єкта), споживання якого і $€$ підставою фрормування пропозиції в туризмі). Отже, основу для розвитку туристичного бізнесу становлять рекреаційно-туристичні ресурси території, тобто ії природно-ресурсний і рекреаційно-ресурсний потенціали.

Природно-ресурсний потенціал - сукупність природних ресурсів туристичного регіону, які використовують або можуть застосовувати в індустрії туризму та гостинності з урахуванням тенденцій їх розвитку. Рекреаційно-ресурсний потенціал території - сукупність природних можливостей конкретного регіону з урахуванням культурно-історичних і соціально-економічних передумов, що сформувалися, для організації різноманітної рекреаційної діяльності, спрямованої на поліпшення здоров'я людей та відновлення сил місцевого та приїжджого для відпочинку населення. Логістика туризму цю властивість галузі враховує особливим чином: в її комплексній структурі логістиці рекреаційнотуристичних ресурсів належить важливе місце, зокрема у складі компонентної структури. Логістику ресурсної бази туризму можна розглядати на різних регіональних рівнях, починаючи від локального (логістика туру) та закінчуючи найвищим - метарівнем (логістика світового туризму). Отже, свою окрему ресурсну базу має кожен туристичний об'єкт, місто, туристична зона, область, регіон, країна, туристичний макрорегіон світу та світ загалом. Місткість ресурсної бази (наявність і величина рекреаційно-ресурсного потенціалу) визначає 
місткість туристичного ринку певної території. Поняття природноресурсного та рекреаційно-ресурсного потенціалів, місткість ландшафту та рекреаційних ресурсів взаємопов'язані та інтегруються в ширшу категорію - логістичний потенціал рекреаційно-туристичних ресурсів (PTP) або ресурсної базитуризму (РБТ), який у системі логістики туризму певного регіону діє разом з логістичним потенціалом матеріальнотехнічної бази туризму (визначальні поняття - місткість туристичної території та місткість розміщення) та логістичним потенціалом вхідного туристопотоку в регіон (визначальні поняття - споживач турпродукції та туристичне споживання).

\section{спИСОК ПОСИЛАНЬ}

Дербак, М.Ю., Обозний, В.В., \& Смирнов, І.Г. (2013). Інноваційна діяльність науково-навчального центру "Синевир". Київ: Національний педагогічний університет імені М. П. Драгоманова.

Олійник, Я.Б., \& Смирнов, І.Г. (2011). Міжнародна логістика. Київ: Обрії.

Смирнов, І.Г. (2007). Бізнесові основи міжнародного туризму. Київ: ВПЦ "Київський університет".

Смирнов, І.Г. (2009а). Логістика туризму. Київ: Знання.

Смирнов, І.Г. (2009b). Міжнародний туристичний бізнес. Івано-Франківськ: Галицька академія.

Смирнов, І.Г. (2014а). Логістика виставкової діяльності: регіональний аспект. Економічна та соціальна географія, 2 (70), 172-182.

Смирнов, І.Г. (2014b). Логістика круїзної компанії як джерело конкурентної переваги на круїзному ринку. В II Літні наукові читання, Матеріали Міжнародної конференції (с. 43-45). Київ: Центр наукових публікацій.

Смирнов, І.Г. (2014c). Логістика та географія круїзного туризму. Часопис соціально-економічної географії, 2, 17-28.

Смирнов, І.Г., \& Волинец, В.В. (2013). Турецький досвід застосування системи "Все включене" в туризмі та можливості його використання в Україні. Наукові записки Київського університету туризму, економіки $i$ права. Серія: філософські науки, 15, 74-89.

\section{REFERENCES}

Derbak, M.Yu., Oboznyi, V.V., \& Smyrnov, I.H. (2013). Innovatsiina diialnist naukovo-navchalnoho tsentru "Synevyr" [Innovative activity of Synevyr Science and Education Center]. Kyiv: National Pedagogikal Dragomanov University [in Ukrainian].

Oliynyk, Ya. B., \& Smyrnov, I.H. (2011). Mizhnarodna lohistyka [International logistics]. Kiev: Obrii [in Ukrainian].

Smyrnov, I.H. \& Volynets, V.V. (2013). Turetskyi dosvid zastosuvannia systemy "Vse vkliuchene" $v$ turyzmi ta mozhlyvosti yoho vykorystannia $v$ Ukraini [Turkish experience in using the "All Inclusive" system in tourism and its use in Ukraine]. Naukovi zapysky Kyivskoho universytetu turyzmu, ekonomiky i prava. Seriia: filosofski nauky, 15, 74-89 [in Ukrainian]. 
Smyrnov, I.H. (2007). Biznesovi osnovy mizhnarodnoho turyzmu [Business fundamentals of international tourism]. Kyiv: VPTs "Kyivskyi universytet" [in Ukrainian].

Smyrnov, I.H. (2009a). Lohistyka turyzmu [Tourism logistics]. Kyiv: Znannia [in Ukrainian].

Smyrnov, I.H. (2009b). Mizhnarodnyi turystychnyi biznes [International Travel Business]. Ivano-Frankivsk: Halytska akademiia [in Ukrainian].

Smyrnov, I.H. (2014b). Lohistyka kruiznoi kompanii yak dzherelo konkurentnoi perevahy na kruiznomu rynkuiu [Logistics of the cruise company as a source of competitive advantage in the cruise market]. In II Litni naukovi chytannia [II Summer Scientific Readings], Proceedings of Materialy Mizhnarodnoi konferentsii. (pp. 43-45). Kyiv: Center for Publications [in Ukrainian].

Smyrnov, I.H. (2014c). Lohistyka ta heohrafiia kruiznoho turyzmu [Logistics and geography of cruise tourism]. Journal of Socio-Economic Geography, 2, 17-28 [in Ukrainian].

Smyrnov, I.H. (2014a). Lohistyka vystavkovoi diialnosti: rehionalnyi aspekt. [Logistics of Exhibition Activity: Regional Aspect]. Ekonomichna ta sotsialna heohrafiiay, 2 (70), 172-182 [in Ukrainian].

\section{UDC 338.48-44(1-21)}

\section{Ihor Smyrnov,}

Dr. of Geographical Sciences, Professor,

Taras Shevchenko National University of Kyiv,

Kyiv, Ukraine

Smirnov_IG@ukr.net

https://orcid.org/0000-0002-6395-7251

\section{COMPLEX LOGISTIC STRATEGY FOR SUSTAINABLE DEVELOPMENT OF URBAN TOURISM: UKRAINIAN AND WORLD EXPERIENCE}

The article is devoted to the justification of a comprehensive logistics strategy for the development of urban tourism based on studies of Ukrainian and international experience. Findings. It was determined that in the complex structure of tourism logistics, logistics of recreational and tourist resources occupy an important place. The logistics of the tourism resource base can be viewed at various regional levels, ranging from local to the highest, the meta-level. Each tourist site, city, tourist zone, area, region, country, tourist macro-region of the world and the world as a whole have a resource base. The capacity of the resource base determines the tourist market content of a certain territory. The concept of natural resource and recreational resource potential, landscape capacity and recreational resources are interconnected and integrated into a wider category - the logistic potential of recreational tourism resources (RTR) or tourism resource base (RBT), which in the tourism logistics system of a particular region operate along with the logistics potential of the material and technical base of tourism and the logistics potential of the incoming tourist traffic in the region.

Keywords: urban tourism, complex logistic strategy, sustainable tourism, Ukrainian experience.

(С) Смирнов І., 2018 